\title{
Model pendampingan dinas sosial dalam menurunkan tingkat kekerasan terhadap anak
}

\author{
Abu Nawar, Joko Setyoko \\ Program Studi Ilmu Pemerintahan, Fakultas Ilmu Sosial dan Ilmu Politik, Universitas Muara Bungo. \\ Jalan Diponegoro No. 27, Muara Bungo-Jambi, Indonesia \\ * Corresponding Author. E-Mail: umbfisipol2017@yahoo.co.id
}

\begin{tabular}{ll}
\hline \hline \multicolumn{1}{c}{ Info Artikel } & \multicolumn{1}{c}{ Abstrak } \\
\hline \hline Histori Artikel: & Tujuan dilakukan penelitian ini adalah untuk mengetahui model pendampingan Dinas \\
Received: 9 Dec. 2019 & Sosial Pengendalian Penduduk Keluarga Berencana Pemberdayaan Perempuan dan \\
Revision: 18 Dec. 2019 & Perlindungan Anak (Dinsos P2KBP3A) dalam menurunkan tingkat kekerasan terhadap \\
Accepted: 31 Dec. 2019 & anak di Kabupaten Bungo. Penelitian ini adalah penelitian kualitatif yang bersifat studi \\
Kata Kunci: model & deskriptif. Teknik pemilihan informan yang digunakan oleh peneliti dalam penelitian \\
pendampingan; sosial; & ini adalah dengan menggunakan metode purposive sampling (teknik penentuan sampel \\
tingkat kekerasan; anak; & dengan pertimbangan tertentu). Hasil penelitian ini menunjukkan bahwa Model \\
assistance model; social; & pendampingan yang dilakukan Dinas Sosial merupakan pendampingan dalam bentuk \\
level of violence; & anggaran dan kebijakan, namun untuk pelaksanaan pendampingan secara langsung \\
children & terhadap anak sebagai korban tindak kekerasan dilakukan oleh Pusat Pelayanan \\
& Terpadu Pemberdayaan Perempuan dan Anak (P2TP2A), beberapa pendampingan \\
& yang dilakukan P2TP2A terhadap anak korban kekerasan yaitu pendampingan medis, \\
& pendampingan psikologis, dan pendampingan yuridis. Beberapa hambatan yang \\
& dialami Dinas Sosial Pengendalian Penduduk Keluarga Berencana Pemberdayaan \\
& Perempuan dan Perlindungan Anak (Dinsos P2KBP3A) dalam menurunkan tingkat \\
& kekerasan terhadap anak di Kabupaten Bungo, diantaranya adalah minimnya \\
& Pengetahuan masyarakat dan orang tua tentang Kekerasan terhadap anak dan \\
& minimnya partisipasi masyarakat dalam melaporkan kejadian tindak kekerasan pada \\
& anak. Upaya Dinas Sosial Pengendalian Penduduk Keluarga Berencana Pemberdayaan \\
& Perempuan dan Perlindungan Anak (Dinsos P2KBP3A) dalam mengatasi hambatan \\
& untuk menurunkan tingkat kekerasan terhadap anak di Kabupaten Bungo, diantaranya \\
& adalah meningkatkan sosialisasi ke masyarakat dan penyediaan rumah aman. \\
\hline \hline
\end{tabular}

The purpose of this research is to find out the assistance model of the Social Service for Population Control for Family Planning for Women's Empowerment and Child Protection (Dinsos P2KBP3A) in reducing the level of violence against children in Bungo District. This research is a qualitative study which studies descriptive studies. The method used in this study is a qualitative research method that is descriptive in nature. The informant selection technique used by researchers in this study is to use a purposive sampling method (sampling technique with certain considerations). The results of this study indicate that the Mentoring Model conducted by the Social Service is a form of assistance in the form of budgets and policies, but for the implementation of direct assistance to children as victims of violence carried out by the Integrated Service Center for Empowering Women and Children (P2TP2A), some assistance is carried out by P2TP2A against child victims of violence, namely medical assistance, psychological assistance, and juridical assistance. Some of the obstacles experienced by the Social Service Population Control Family Planning for Women's Empowerment and Child Protection (Dinsos P2KBP3A) in reducing the level of violence against children in Bungo District, including the lack of community and parental knowledge about violence against children and the lack of community participation in reporting incidents of violence in children. The Efforts of the Social Service for Population Control of Family Planning for Women's Empowerment and Child Protection (Dinsos $P 2 K B P 3 A)$ in overcoming obstacles to reducing the level of violence against children in Bungo District, including increasing socialization to the community and providing safe houses.

This work is licensed under a Creative Commons Attribution-ShareAlike 4.0 International License.

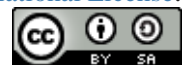




\section{PENDAHULUAN}

Perlindungan Anak adalah Segala kegiatan yang menjamin dan melindungi anak dan hakhaknya agar dapat hidup, tumbuh, berkembang, dan berpartisipasi, secara optimal sesuai dengan harkat dan martabat kemanusiaan, serta mendapat perlindungan dari kekerasan dan diskriminasi, demi terwujudnya anak Indonesia yang berkualitas, berakhlak mulia, dan sejahtera (Presiden Republik Indonesia, 2002). Berdasarkan data yang dimiliki Komisi Perlindungan Anak Indonesia (KPAI), sepanjang tahun 2017 telah menerima pengaduan 2.737 kasus kekerasan pada anak (Setyawan, 2014). Angka ini menurun bila dibandingkan laporan yang diterima tahun 2016, yakni 3.339 kasus. Dari angka 2.737 tersebut, 52 persen lebih didominasi kejahatan seksual. Total keseluruhan korban dari laporan yang diterima sepanjang 2017 adalah 2.848. Dengan korban anak laki-laki yang paling banyak menjadi sasaran predator, jumlahnya 59 persen. Sementara jumlah korban anak perempuan mencapai 40 persen (Setyawan, 2014).

Upaya pencegahan tindak kekerasan terhadap anak bukan hanya tugas orangtua dan masyarakat tetapi negara ikut andil dalam hal tersebut. Negara adalah suatu organisasi dalam suatu wilayah yang memiliki kekuasaan tertinggi yang sah dan ditaati oleh rakyatnya. Tujuan Negara menurut Roger $\mathrm{H}$. Soltau, adalah memungkinkan rakyatnya berkembang serta menyelenggarakan daya ciptanya sebebas mungkin dan menciptakan keadaan dimana rakyat dapat mencapai keinginan-keinginan mereka secara maksimal (Iriani, \& Iziyana, 2019; Noerwiyati, 2017; Thohari, 2005).

Semua anak memiliki hak untuk dilindungi dari kekerasan, eksploitasi dan pelecehan. Oleh karena itu orang tua dan orang dewasa (termasuk pemerintah) berkewajiban melindungi mereka. Hal ini sesuai dengan yang tercantum di dalam Undang-Undang tentang Perlindungan Anak yaitu UU Nomor 23 Tahun 2002 pada Bab III Pasal 13, yang berbunyi "Setiap anak selama dalam pengasuhan orang tua, wali, atau pihak lain mana pun bertanggung jawab atas pengasuhan, berhak mendapat perlindungan dari perlakuan: diskriminasi, eksploitasi baik ekonomi maupun seksual, penelantaran, kekejaman, kekerasan, dan penganiayaan." (Presiden Republik Indonesia, 2002).

Setiap keluarga memiliki cara untuk menyelesaikan masalahnya masing-masing, yang perlu dihindari adalah penyelesaian masalah yang dilakukan dengan marah yang berlebih-lebihan, hentakan fisik sebagai pelampiasan kemarahan, teriakan dan makian maupun ekspresi wajah menyeramkan, terkadang muncul perilaku seperti menyerang, memaksa, mengancam atau melakukan kekerasan fisik. Karena perilaku tersebut merupakan bentuk tindakan kekerasan dalam rumah tangga (KDRT) (Sari, 2015).

Anak yang menjadi korban kekerasan tentu akan mengalami trauma baik fisik maupun psikisnya. Anak yang mengalami kekerasan di masa lalunya akan berpotensi untuk melakukan tindak kekerasan (pelaku) ketika mereka dewasa. Oleh karena itu anak yang menjadi korban kekerasan perlu mendapatkan perhatian khusus dan penanganan secara khusus yang melibatkan orang tua, keluarga, pemerintah, dan peran serta masyarakat. Sesuai yang tercantum pada pasal 20 Undang-Undang Nomor 23 Tahun 2002 tentang Perlindungan Anak adalah: "Negara, pemerintah, masyarakat, keluarga dan orang tua berkewajiban dan bertanggungjawab terhadap penyelenggaraan perlindungan anak." (Presiden Republik Indonesia, 2002).

Berdasarkan wawancara awal peneliti dengan pegawai pada Dinas Sosial Pengendalian Penduduk Keluarga Berencana Pemberdayaan Perempuan dan Perlindungan Anak Kabupaten Bungo diketahui bahwa terdapat beberapa permasalahan dalam penanganan kasus tindak kekerasan terhadap anak, diantaranya adalah: (1) Masih sulitnya mendapatkan data akurat tentang kekerasan terhadap anak, karena tidak semua korban mau melaporkan kejadian kepada Dinas Sosial P2KB dan P3A; (2) Masih kurangnya pengetahuan masyarakat tentang perlunya perlindungan anak; dan (3) Masih adanya budaya malu dan tabu untuk melaporkan kekerasan dalam rumah tangga, sehingga banyak kejadian yang telah berlarut-larut menyebabkan penyelesaian kasus menjadi rumit.

Berdasarkan data Pusat Pelayanan Terpadu Pemberdayaan Perempuan (P2TP2) Kabupaten Bungo diketahui bahwa terjadi penurunan laporan kasus kekerasan dalam rumah tangga yang terjadi baik terhadap anak maupun perempuan, sebagaimana terlihat pada Tabel 1.

Berdasarkan Tabel 1 diketahui bahwa tingkat kekerasan dalam rumah tangga selalu menurun setiap tahunnya, kondisi tidak terlepas adanya pendampingan yang dilakukan oleh Dinas Sosial Pengendalian Penduduk Keluarga Berencana Pemberdayaan Perempuan dan Perlindungan Anak (DINSOS P2KBP3A) dalam menurunkan tingkat kekerasan terhadap anak di Kabupaten Bungo, 
Jurnal Politik dan Pemerintah Daerah, 1 (2), 2019 - 63

Abu Nawar, Joko Setyoko

namun pada tabel terlihat ada peningkatan di tahun 2018 dimana terdapat kasus penelantaran terhadap anak.

Tabel 1. Rekapitulasi Data Kekerasan Dalam Rumah Tangga (KDRT)

\begin{tabular}{|c|c|c|c|c|c|c|c|}
\hline \multirow{2}{*}{ No. } & \multirow{2}{*}{ Tahun } & \multicolumn{4}{|c|}{ Banyaknya Laporan KDRT } & \multirow{2}{*}{ Jumlah Kasus } & \multirow{2}{*}{ Keterangan } \\
\hline & & Fisik & Psikis & Penelantaran & Seksual & & \\
\hline 1. & 2015 & 27 & & & 13 & 40 & \\
\hline 2. & 2016 & 28 & & & 5 & 33 & \\
\hline 3. & 2017 & 3 & & & 2 & 5 & \\
\hline 4. & 2018 & 6 & & 1 & 2 & 5 & Per April 2018 \\
\hline
\end{tabular}

Berdasarkan femonema tersebut peneliti tertarik untuk melakukan penelitian dengan judul "Model Pendampingan Dinas Sosial Pengendalian Penduduk Keluarga Berencana Pemberdayaan Perempuan dan Perlindungan Anak (DINSOS P2KBP3A) dalam Menurunkan Tingkat Kekerasan Terhadap Anak di Kabupaten Bungo".

\section{METODE}

Dalam penelitian ini yang menjadi lokasinya adalah Dinas Sosial Pengendalian Penduduk Keluarga Berencana Pemberdayaan Perempuan dan Perlindungan Anak (Dinsos P2KBP3A) Kabupaten Bungo. Alasan memilih lokasi ini dikarenakan Dinas Sosial Pengendalian Penduduk Keluarga Berencana Pemberdayaan Perempuan dan Perlindungan Anak Kabupaten Bungo merupakan instansi pemerintah yang memiliki kewenangan dalam hal perlindungan anak. Penelitian ini dilaksanakan pada bulan Juni - Agustus 2018.

Metode yang digunakan dalam penelitian ini penelitian ini adalah metode penelitian deskriptif kualitatif. Menurut Moleong (2007) penelitian deskriptif kualitatif adalah penelitian yang bermaksud untuk memahami fenomena tentang apa yang dialami oleh subjek penelitian, misalnya perilaku, persepsi, motivasi, tindakan, dll., secara holistik dan dengan cara deskripsi dalam bentuk kata-kata dan bahasa, pada suatu konteks khusus yang alamiyah dan dengan memanfaatkan berbagai metode alamiah (Moleong, 2007).

\section{Teknik Pengumpulan Data}

Teknik pengumpulan data yang digunakan dalam penelitian ini adalah observasi, dokumentasi, dan wawancara.

\section{Observasi}

Observasi yaitu pengamatan langsung terhadap objek yang akan diteliti. Dalam penelitian ini, peneliti langsung ke lapangan untuk mengamati. Hasil observasi atau pengamatan ini kemudian dituangkan dalam bentuk catatan lapangan. Cara seperti ini dilakukan untuk mengenal secara lebih dekat kondisi dan situasi objek penelitian. Dengan observasi, data yang di kumpulkan cenderung mempunyai keandalan yang tinggi. Hal-hal yang di observasi dalam penelitian ini proses pendampingan terhadap anak yang mendapat kekerasan.

\section{Dokumentasi}

Dokumentasi dari asal katanya dokumen, yang artinya barang-barang tertulis. Di dalam melaksanakan metode dokumentasi, peneliti menyelidiki benda-benda tertulis seperti buku-buku, majalah, dokumen, peraturan-peraturan, notulen rapat, catatan harian, dan sebagainya (Arikunto, 2006). Peneliti melakukan dokumentasi pelaksanaan kegiatan penelitian melalui foto atau gambar, sebagai bukti fisik pelaksanaan penelitian.

Wawancara mendalam

Dalam wawancara ini terjadi percakapan antara pewawancara dengan yang diwawancarai dalam suasana santai, kurang formal dan tidak disediakan jawaban oleh pewawancara. Wawancara ini dimaksudkan untuk memperoleh informasi yang sifatnya mendalam terhadap masalahmasalah yang diajukan. Kelonggaran ini diharapkan mampu mengorek dan menangkap kejujuran informan, sehingga diperoleh informasi yang sebenarnya. 


\section{Sumber Data}

\section{Data Primer}

Data primer adalah data yang diperoleh langsung dari informan. Yang termasuk data primer adalah transkrip hasil wawancara dan hasil temuan-temuan saat proses pelaksanaan penelitian

Data Sekunder

Data sekunder yaitu data yang diperoleh secara tidak langsung dari objek penelitian. Pengumpulan data sekunder dalam penelitian ini dengan cara penelitian kepustakaan dan pencatatan dokumen, yaitu dengan mengumpulkan data dan mengambil informasi dari buku-buku referensi, dokumen, foto, majalah, jurnal, artikel dan internet yang dianggap relevan dengan masalah yang diteliti.

\section{Teknik Penentuan Informan}

Teknik pemilihan informan yang digunakan oleh peneliti dalam penelitian ini adalah dengan menggunakan metode purposive sampling (teknik penentuan sampel dengan pertimbangan tertentu) karena dalam teknik purposive sampling ini sudah ditetapkan terlebih dahulu siapa saja yang akan dijadikan informan dalam penelitian ini yaitu dilakukannya dengan cara mengambil subjek bukan berdasarkan atas strata random atau daerah tetapi berdasarkan atas adanya tujuan tertentu dan dilakukannya karena beberapa pertimbangan diantaranya adalah populasi yang dipilih untuk dijadikan sampel dapat dipilih sedemikian rupa menurut kriteria-kriteria yang telah ditentukan sehingga akan relevan dengan rencana penelitian. Tabel 2 merupakan daftar calon informan:

Tabel 2. Daftar Informan

\begin{tabular}{cllc}
\hline No. & \multicolumn{1}{c}{ Nama } & \multicolumn{1}{c}{ Jabatan } & Jumlah \\
\hline 1. & Ir. Suryawani, ME & Kepala Dinas Sosial P2KB dan P3A & 1 \\
2. & Osbon Tambunan, SE & Kepala Seksi Perlindungan Anak & 1 \\
3. & Bunga (nama samaran) & Anak (korban) & 1 \\
4. & H. Sanusi & Tokoh Masyarakat & 1 \\
5. & Systam Efendi & P2TP2 & 1 \\
6. & Kulup (nama samaran) & Pelaku Tindak Kekerasan & 1 \\
Total & & & 7 \\
\hline
\end{tabular}

\section{Analisis Data}

Analisis data dalam penelitian ini dilakukan secara induktif, yaitu analisa yang dimulai dari pengumpulan data, reduksi data, penyajian data, dan verifikasi data. Data-data yang diperoleh dari lapangan akan diatur, diurutkan, dikelompokkan ke dalam kategori, pola atau uraian tertentu. Analisis data dimulai dengan menelaah seluruh data yang tersedia dari berbagai sumber, yaitu pengamatan dan wawancara mendalam, yang sudah dituliskan dalam catatan lapangan. Dalam proses analisis data dimulai dengan menelaah seluruh data yang diperoleh dari berbagai sumber antara lain dari wawancara, pengamatan lapangan yang sudah ditulis dalam cacatan lapangan, serta dokumen yang telah diperoleh. Kemudian diseleksi, ditelaah serta dikaji lalu diabstraksikan. Abstraksi yang dimaksud adalah usaha membuat rangkuman inti proses dan pernyataan-pernyataan yang perlu dijaga sehingga tetap dalam koridor penelitian.

Setelah data terkumpul, disusun dalam lembar-lembar rangkuman, selanjutnya peneliti mengidentifikasi data yang ada untuk masing-masing pokok permasalahan dalam lembar tersendiri. Hal ini dimaksudkan agar peneliti lebih mudah melakukan pengecekan terhadap setiap data yang ada. Pengecekan ini dilakukan karena tidak semua informan sama dalam memberikan jawaban terhadap suatu permasalahan, untuk lebih memantapkan kesimpulan yang akan diambil peneliti. Bila dirasa ada kekurangan dalam reduksi data maupun sajian data maka dilakukan penggalian data kembali dalam cacatan lapangan dan terjun kembali ke lapangan. Setelah data yang diharapkan terkumpul semua, barulah menarik kesimpulan untuk setiap pokok permasalahan yang ada 


\title{
Defenisi Operasional dan Konseptual
}

\author{
Defenisi Operasional
}

Operasional merupakan batasan pengertian tentang variabel yang diteliti yang di dalamnya sudah mencerminkan indikator-indikator yang akan digunakan untuk mengukur variabel yang bersangkutan. Namun demikian, sebaik-baiknya definisi operasional adalah definisi yang merujuk atau berlandasan pada definisi konseptual. Dapat juga didefinisikan variabel secara operasional berdasarkan karakteristik yang diamati, sehingga memungkinkan peneliti untuk melakukan observasi atau pengamatan secara cermat terhadap suatu objek. Operasional juga merupakan unsur penelitian yang menggambarkan bagaimana caranya mengukur suatu variabel, dengan kata lain definisi operasional adalah semacam petunjuk pelaksanaan bagaimana caranya menyangkut suatu variabel.

Defenisi operasional dalam penelitian ini dapat dijelaskan sebagai berikut: Pendampingan Dinas diukur dengan indikator: (1) Dengan melihat model pendampingan Dinas Sosial Pengendalian Penduduk Keluarga Berencana Pemberdayaan Perempuan dan Perlindungan Anak dalam menurunkan tingkat kekerasan terhadap anak di Kabupaten Bungo; (2) Dengan melihat hambatan-hambatan Dinas Sosial Pengendalian Penduduk Keluarga Berencana Pemberdayaan Perempuan dan Perlindungan Anak dalam menurunkan tingkat kekerasan terhadap anak di Kabupaten Bungo; (3) Dengan melihat upaya Dinas Sosial Pengendalian Penduduk Keluarga Berencana Pemberdayaan Perempuan dan Perlindungan Anak dalam mengatasi hambatan untuk menurunkan tingkat kekerasan terhadap anak di Kabupaten Bungo.

Defenisi Konseptual

Defenisi Konseptual dalam penelitian ini dapat dijelaskan sebagai berikut:

\section{Model pendampingan}

Sejauh mana Dinas Sosial Pengendalian Penduduk Keluarga Berencana Pemberdayaan Perempuan dan Perlindungan Anak (Dinsos P2KBP3A). Memberikan pendampingan dalam kasus tindak kekerasan terhadap anak. Sebutan pendamping dalam sistem hukum Indonesia dikenal sejak diundangkan-nya undang-undang No. 23 tahun 2002 tentang Perlindungan Anak (UUPA). Pendamping menurut pasal 1 ayat 12 UU Perlindungan Anak adalah pekerja sosial yang mempunyai kompetensi profesional dalam bidangnya, UU Perlindungan anak tidak menjelaskan secara khusus peran dari seorang pendamping dalam menangani korban (Presiden Republik Indonesia, 2002).

\section{Pemerintah Daerah}

Pemerintah daerah adalah kepala daerah beserta perangkat daerah otonom yang lain sebagai badan eksektutif daerah.

\section{Dinas Sosial Pengendalian Penduduk Keluarga Berencana Pemberdayaan Perempuan dan Perlindungan Anak (Dinsos P2KBP3A)}

Dinas Sosial, Pengendalian Penduduk, Keluarga Berencana, Pemberdayaan Perempuan dan Perlindungan Anak Kabupaten Bungo merupakan unsur pelaksana Pemerintahan Daerah yang bertugas mengkoordinasikan dan mengendalikan seluruh kegiatan Dinas dalam menyelenggarakan penyusunan dan pelaksanaan kebijakan daerah di bidang sosial, pengendalian penduduk dan keluarga berencana, pemberdayaan perempuan dan perlindungan anak di Kabupaten Bungo.

\section{Kekerasan}

Kekerasan adalah pemakaian kekuatan yang tidak adil, dan tidak dapat dibenarkan, yang disertai dengan emosi yang hebat atau kemarahan yang tidak terkendali, tiba-tiba, bertenaga, kasar dan menghina.

Anak

Anak adalah seseorang yang belum berusia 18 (delapan belas) tahun, termasuk anak yang masih dalam kandungan. 
Perlindungan Anak

Perlindungan anak bertujuan untuk menjamin terpenuhinya hak-hak anak agar dapat hidup, tumbuh, berkembang, dan berpartisipasi secara optimal sesuai dengan harkat dan martabat kemanusiaan, serta mendapat perlindungan dari kekerasan dan diskriminasi, demi terwujudnya anak Indonesia yang berkualitas, berakhlak mulia, dan sejahtera.

\section{HASIL DAN PEMBAHASAN}

\section{Model Pendampingan Dinas Sosial Pengendalian Penduduk Keluarga Berencana Pemberdayaan Perempuan dan Perlindungan Anak (Dinsos P2KBP3A) dalam menurunkan tingkat kekerasan terhadap anak di Kabupaten Bungo}

Hasil penelitian yang dilakukan di Dinas Sosial Pengendalian Penduduk Keluarga Berencana Pemberdayaan Perempuan dan Perlindungan Anak (Dinsos P2KBP3A) Kabupaten Bungo diketahui bahwa model pendampingan yang dilakukan Dinas Sosial merupakan pendampingan dalam bentuk anggaran dan kebijakan, namun untuk pelaksanaan pendampingan secara langsung terhadap anak sebagai korban tindak kekerasan dilakukan oleh Pusat Pelayanan Terpadu Pemberdayaan Perempuan dan Anak (P2TP2A), hal ini sebagaimana disampaikan oleh Ibu Suryawani selaku Kepala Dinas Sosial P2KBP3A, berikut kutipannya:

“...untuk pendampingan secara langsung terhadap korban tindak kekerasan bukan Dinas sosial, namun dibawah naungan Dinas Sosial terdapat Pusat Pelayanan Terpadu Pemberdayaan Perempuan dan Anak (P2TP2A) mereka inilah yang melakukan pencegahan, pendampingan dan penyelesaian kasus tindak kekerasan terhadap anak.." 1

Selanjutnya beliau menambahkan:

“...hanya saja pendampingan yang kita berikan dalam bentuk kebijakan dan anggaran, jadi anggaran yang ada pada P2TP2A tersebut merupakan anggaran dari Dinas Sosial, kemudian kebijakan kita termasuk memberikan ruang untuk sekretariat serta upaya penyediaan rumah aman bagi korban" 2

Pendapat yang sama juga disampaikan oleh Osbon Tambunan selaku Kepala Seksi Perlindungan Anak pada Dinas Sosial P2KB dan P3A Kabupaten Bungo:

“...pendampingan itu yang melaksanakan adalah P2TP2A, kita hanya mengusulkan anggaran serta kebijakan lainnya yang mendukung kegiatan P2TP2A tersebut, sementara untuk pelaksanaanya adalah P2TP2A, meskipun terdapat pegawai Dinas Sosial dalam struktur kelembagaan tersebut namun mereka mengatasnamakan P2TP2A bukan selaku pegawai Dinas Sosial.." 3

Beliau melanjutkan:

“...Pusat pelayanan terpadu pemberdayaan perempuan daan anak merupakan wadah pelayanan pemberdayaan perempuan dan anak yang berbasis masyarakat, dalam melaksanakan tugasnya P2TP2A memiliki bagian-bagian sesuai dengan kebutuhan dan pokok permasalahan yang menjadi fokus untuk ditangani yaitu perempuan dan anak di wilayah kabupaten Bungo.." 4

Berdasarkan pernyataan tersebut dapat dipahami bahwa keberdaan P2TP2A tidak terlepas dari amanat yang disampaikan Undang-Undang Nomor 23 tahun 2004 Tentang Penghapusan Kekerasan Dalam Rumah Tangga, dan dalam pelaksanaannya diatur dalam Peraturan Pemerintah Nomor 4 Tahun 2006 tentang Penyelenggaraan dan Kerja Sama Pemulihan Korban Kekerasan Dalam Rumah Tangga

${ }^{1}$ Wawancara dengan Ibu Suryawani selaku Kepala Dinas Sosial P2KB dan P3A Kabupaten Bungo, tanggal 3 Agustus 2018

2 Wawancara dengan Ibu Suryawani selaku Kepala Dinas Sosial P2KB dan P3A Kabupaten Bungo, tanggal 3 Agustus 2018

${ }^{3}$ Wawancara dengan Bapak Osbon Tambunan selaku Kepala Seksi Perlindungan Anak pada Dinas Sosial P2KB dan P3A Kabupaten Bungo, tanggal 8 Agustus 2018

${ }^{4}$ Wawancara dengan Bapak Osbon Tambunan selaku Kepala Seksi Perlindungan Anak pada Dinas Sosial P2KB dan P3A Kabupaten Bungo, tanggal 8 Agustus 2018 
Jurnal Politik dan Pemerintah Daerah, 1 (2), 2019 - 67

Abu Nawar, Joko Setyoko

Pasal 5 ayat (5) yang berbunnyi "Resosialisasi korban dilaksanakan oleh instansi sosial dan lembaga sosial agar korban dapat kembali melaksanakan fungsi sosialnya dalam masyarakat"

Pusat Pelayanan Terpadu Pemberdayaan Perempuan dan Anak (P2TP2A) Kabupaten Bungo sebagaimana tercantum Peraturan Daerah Kabupaten Bungo nomor 7 tahun 2018 tentang Perlindungan Anak, secara umum P2TP2A mempunyai tugas untuk memberikan pelayanan yang cepat dan tepat dalam rangka memberikan perlindungan terhadap anak yang rentan terhadap tindak kekerasan, eskploitasi, perlakuan salah dan penelantaran anak (Bupati Bungo, 2018).

“...intinya kita (P2TP2A) bertugas untuk mendorong agar hak-hak anak korban tindak kekeras terpenuhi, seperti hak mendapatkan pendampingan secara hukum maupun psikis mereka.." 5

Beliau menambahkan:

“..beberapa kejadian yang kami tangani diantaranya adalah kasus kekerasan seksual terhadap anak, di Rantau Pandan beberapa waktu yang lalu, dimana kasus itu bermula dari adanya pelecehan seksual yang dilakukan oleh ayah kandung si korban, karena merasa trauma dengan perlakuan tersebut kemudian si korban tidur dengan kakeknya, namun malangnya anak tersebut malah menjadi korban dari kakeknya sendiri, dalam kondisi tersebu tentunya keberadaan P2TP2A sangat diharapkan untuk menyelesaikan permasalahan tersebut, tidak hanya dari segi hukum saja, namun bagaimana anak tersebut bisa sekolah dan tidak terjadi trauma mental pada anak.." ${ }^{6}$

Beliau juga menjelaskan:

“...zaman sekarang ini tindak kekerasan terhadap anak itu lebih banyak dilakukan oleh orang terdekat korban, seperti orang tua korban sendiri yang melakukan kekerasan fisik dengan memukul dan lain sebagainya, serta kekerasan seksual yang dilakukan juga oleh orang terdekat korban, seperti tetangga, keluarga, atau teman sepermainan.." 7

Pernyataan tersebut menggambarkan bahwa hal yang melatarbelakangi kegiatan pendampingan anak korban kekerasan adalah peningkatan jumlah kekerasan baik kekerasan fisik, psikis maupun seksual yang dialami anak pada tiap tahunnya, baik yang dilakukan oleh orang lain maupun oleh anggota keluarganya sendiri. Tujuan utama dari pendampingan di Lembaga P2TP2A Kabupaten Bungo ini adalah mengembalikan kondisi anak pada keberfungsian sosial.

Kegiatan pendampingan anak korban kekerasan di Lembaga P2TP2A Kabupaten Bungo berupa pendampingan medis, psikologis dan yuridis. Tugas pendamping disini membantu anak untuk mengentaskan/membantu menyelesaikan permasalahannya. Pendamping juga melakukan penguatan kepada keluarga berupa sosialisasi pada keluarga mengenai apa itu P2TP2A Kabupaten Bungo, tugas P2TP2A. Selain sosialisasi, P2TP2A Kabupaten Bungo juga mengadakan sharing tentang keluh kesah dan harapan orang tua terhadap P2TP2A Kabupaten Bungo ini, penguatan keluarga dilakukan juga untuk menyiapkan keluarga agar dapat menerima kondisi anak. Selain itu, ada juga untuk pemenuhan kebutuhan anak. Pemenuhan kebutuhan anak disini meliputi kebutuhan sandang, pangan dan papan. Hasil yang ingin dicapai dari kegiatan pendampingan ini adalah social fungtion (keberfungsian sosial) anak dapat kembali seperti sebelumnya. Hal ini sebagaimana diungkapkan Bapak Osbon Tambunan selaku Kepala Seksi Perlindungan Anak:

“....karena saya juga bagian dari P2TP2A maka saya paham betul bagaimana kondisi di masyarakat, maka kita melakukan sosialisasi apa saja fungsi dan tugas P2TP2A, sebab kita sadar betul banyak sekali kejadian yang terjadi dalam rumah tangga (KDRT) terhadap anak yang tidak dilaporkan oleh anggota keluarga yang lain karena takut, maka kita sampaikan perlindungan yang kita berikan apasaja.." 8

Pendapat yang sama juga disampaikan oleh Bapak Systam Efendi selaku Kepala P2TP2 Kabupaten Bungo:

\footnotetext{
${ }^{5}$ Wawancara dengan Systam Efendi selaku P2TP2 Kabupaten Bungo, tanggal 7 Agustus 2018

${ }^{6}$ Wawancara dengan Systam Efendi selaku P2TP2 Kabupaten Bungo, tanggal 7 Agustus 2018

${ }^{7}$ Wawancara dengan Systam Efendi selaku P2TP2 Kabupaten Bungo, tanggal 7 Agustus 2018

${ }^{8}$ Wawancara dengan Bapak Osbon Tambunan selaku Kepala Seksi Perlindungan Anak pada Dinas Sosial P2KB dan P3A Kabupaten Bungo, tanggal 8 Agustus 2018
} 
“..banyak sekali kejadian kekerasan seksual yang terjadi di masyarakat khususnya dalam keluarga sendiri namun tidak dilaporkan, seperti yang dilakukan paman terhadap keponakanya sendiri atau bahkan orang tua kandung terhadap anak, ayah tiri terhadap anaknya, biasanya korban diancam sehingga tidak berani cerita atau melaporkan perlakuan yang mereka dapatkan.." 9

Berdasarkan hasil wawancara diketahui bahwa terdapat beberapa pendampingan yang dilakukan P2TP2A terhadap korban kekerasan terhadap anak, diantaranya:

Pendampingan Medis

Berdasarkan hasil wawancara yang dilakukan peneliti dengan Bapak Systam Efendi selaku P2TP2 Kabupaten Bungo, pendampingan medis dilakukan kepada anak/korban yang mengakibatkan luka fisik dan perlunya penanganan lebih lanjut dari pihak medis. Berikut penuturannya:

"kami melakukan pendampingan medis untuk anak yang memerlukan penanganan lebih lanjut dari pihak medis misalnya untuk anak yang memerlukan visum karena tindak kekerasan seksual maka akan kita lakukan pendampingan medis, atau akibat kekerasan fisik tentu kita lakukan pendampingan secara medis" ${ }^{10}$

Beliau melanjutkan:

“...Kenakalan anak adalah hal yang paling sering menjadi penyebab kemarahan orang tua, sehingga anak menerima hukuman dan bila disertai emosi maka orangtua tidak segan untuk memukul atau melakukan kekerasan fisik. Bila hal ini sering dialami oleh anak maka akan menimbulkan luka yang mendalam pada fisik dan batinnya..."

Adanya tindak kekerasan terhadap anak tidak hanya menimbulkan luka fisik namun juga akan menimbulkan kebencian pada orang tuanya dan trauma pada anak. Akibat lain dari kekerasan anak akan merasa rendah harga dirinya karena merasa pantas mendapat hukuman sehingga menurunkan prestasi anak disekolah atau hubungan sosial dan pergaulan dengan teman-temannya menjadi terganggu, hal ini akan mempengaruhi rasa percaya diri anak yang seharusnya terbangun sejak kecil.

Pendampingan psikologis

Berdasarkan hasil wawancara diketahui bahwa pendampingan psikologis dilakukan kepada anak korban kekerasan atau pelaku kekerasan yang mengalami trauma, hilang rasa percaya diri, ketakutan yang luar biasa, cemas dan juga cenderung menutup diri. Hal ini sebagaimana disampaikan oleh Bapak Systam Efendi selaku P2TP2 Kabupaten Bungo:

"pendampingan psikologis dilakukan untuk anak yang mengalami trauma atau untuk anak-anak yang memerlukan penanganan psikologis akibat dari kekerasan yang dialaminya" 11

Selanjutnya beliau menambahkan:

“..kita bekerjsa sama dengan psikolog yang ada di Kabupaten Bungo, jika ada korban yang perlu pendampingan psikologis maka kita akan segera meminta beliau untuk mendampinginya..." 12

Berdasarkan hasil wawancara dapat ditarik kesimpulan bahwa pendampingan psikologis dilakukan kepada anak korban kekerasan atau pelaku kekerasan yang mengalami trauma, hilang rasa percaya diri, ketakutan yang luar biasa, cemas dan juga cenderung menutup diri.

Menurut Bapak Systam Efendi selaku P2TP2 Kabupaten Bungo Diketahui bahwa penyiksaan terhadap anak dapat digolongkan menjadi : ${ }^{13}$

\section{Penyiksaan Fisik}

Segala bentuk penyiksaan secara fisik, dapat berupa cubitan, pukulan, tendangan, menyundut dengan rokok, membakar, dan tindakan-tindakan lain yang dapat membahayakan anak. Banyak

\footnotetext{
${ }^{9}$ Wawancara dengan Systam Efendi selaku P2TP2 Kabupaten Bungo, tanggal 7 Agustus 2018

${ }^{10}$ Wawancara dengan Systam Efendi selaku P2TP2 Kabupaten Bungo, tanggal 7 Agustus 2018

${ }^{11}$ Wawancara dengan Systam Efendi selaku P2TP2 Kabupaten Bungo, tanggal 7 Agustus 2018

${ }^{12}$ Wawancara dengan Systam Efendi selaku P2TP2 Kabupaten Bungo, tanggal 7 Agustus 2018

${ }^{13}$ Wawancara dengan Systam Efendi selaku P2TP2 Kabupaten Bungo, tanggal 7 Agustus 2018
} 
Jurnal Politik dan Pemerintah Daerah, 1 (2), 2019 - 69

Abu Nawar, Joko Setyoko

orangtua yang menyiksa anaknya mengaku bahwa perilaku yang mereka lakukan adalah semata-mata suatu bentuk pendisiplinan anak, suatu cara untuk membuat anak mereka belajar bagaimana berperilaku baik.

\section{Penyiksaan Emosi}

Penyiksaan emosi adalah semua tindakan merendahkan atau meremehkan anak, selanjutnya konsep diri anak terganggu, anak merasa tidak berharga untuk dicintai dan dikasihi. Jenis - jenis penyiksaan emosi antara lain adalah : penolakan, tidak diperhatikan, ancaman dan isolasi.

\section{Pelecehan Seksual}

Pelecehan seksual pada anak adalah kondisi dimana anak terlibat dalam aktivitas seksual, anak sama sekali tidak menyadari, dan tidak mampu mengkomunikasikannya, atau bahkan tidak tahu arti tindakan yang diterimanya. Jenis-jenis penyiksaan seksual adalah : pelecehan seksual tanpa sentuhan (anak melihat pornografi atau ekshibisionisme, dsb), pelecehan seksual dengan sentuhan (semua tindakan pelecehan orang dewasa terhadap organ seksual anak, seperti adanya penetrasi ke dalam alat kelamin anak perempuan dengan benda apapun yang tidak mempunyai tujuan medis dan eksploitasi seksual (meliputi semua tindakan yang menyebabkan anak masuk dalam tujuan prostitusi, atau menggunakan anak sebagai model foto atau film porno).

\section{Pengabaian}

Pengabaian terhadap anak termasuk penyiksaan secara pasif, yaitu segala ketiadaan perhatian yang memadai, baik fisik, emosi maupun sosial. Jenis-jenis pengabaian anak antara lain adalah: Pertama, Pengabaian fisik. Misalnya keterlambatan mencari bantuan medis, pengawasan yang kurang memadai, serta tidak tersedianya kebutuhan akan rasa aman dalam keluarga. Kedua, Pengabaian pendidikan. Misalnya orang tua seringkali tidak memberikan fasilitas pendidikan yang sesuai dengan bakat dan kemampuan anak. Ketiga, Pengabaian secara emosi. Dapat terjadi misalnya ketika orang tua tidak menyadari kehadiran anak ketika sedang bertengkar. Pembedaan perlakuan dan kasih sayang orang tua terhadap anak-anaknya. Keempat, Pengabaian fasilitas medis. Misalnya orang tua tidak menyediakan layanan medis untuk anak meskipun secara finansial memadai. Kelima, Mempekerjakan anak di bawah umur. Hal ini melanggar hak anak untuk memperoleh pendidikan, dapat membahayakan kesehatan, serta melanggar hak mereka sebagai manusia. Anak yang dicurigai telah mengalami penyiksaan fisik perlu di lakukan penyelidikan lebih lanjut yang melibatkan: Pekerja Sosial, Dokter Anak dan Pihak yang berwajib (Polisi).

\section{Pendampingan yuridis}

Menurut Bapak Systam Efendi selaku P2TP2 Kabupaten Bungo pendampingan yuridis dilakukan pada anak-anak korban kekerasan yang tersangkut permasalahan yang berkaitan dengan hukum, berikut penuturannya:

“...bagi anak yang berhadapan dengan hukum maka kita lakukan pendampingan yuridis, baik sebagai korban maupun sebagai pelaku, namun tentunya dengan mempertingkan berbagai aspek, dalam pendampingan yuridis kita lakukan dengan pendampingan dengan pada saat korban diperiksa serta melaporkan jika sebagai korban.." ${ }^{14}$

Selanjutnya beliau melanjutkan:

“...pendampingan yuridis yaitu pendampingan yang dilakukan P2TP2A terhadap anak yang berkonflik dengan hukum. Pendampingan ini mencakup proses di kepolisian, kejaksaan dan pengadilan...." 15

Beliau menjelaskan:

"Adapun cara pendampingan dilakukan melalui melalui home visit. Dalam home visit ini, pendamping langsung mendatangi rumah. Mekanisme dari home visit ini pertama dari pihak P2TP2A mendapat pengaduan dari pihak aparat kepolisian/masyarakat/keluarga mengenai kasus

\footnotetext{
${ }^{14}$ Wawancara dengan Systam Efendi selaku P2TP2 Kabupaten Bungo, tanggal 7 Agustus 2018

${ }^{15}$ Wawancara dengan Systam Efendi selaku P2TP2 Kabupaten Bungo, tanggal 7 Agustus 2018
} 
kekerasan yang dialami anak di suatu tempat. Pengadu datang langsung ke P2TP2A dalam melaporkan kasus kekerasan, pengaduan dapat juga melalui perantara telepon. Setelah mendapatkan laporan, kemudian P2TP2A mempelajari kasus yang dialami oleh anak tersebut sebelum melakukan home visit (kunjungan ke rumah)..."16

Dalam pelaksanaan ini tentunya pihak lembaga bermitra dengan banyak pihak seperti rumah sakit maupun panti sosial untuk anak demi kelancaran proses pendampingan. Setelah selesai pendampingan, kemudian dilakukan oleh evaluasi. Tahap terakhir adalah terminasi (pengakhiran). Apabila pada tahap pengakhiran ini, klien membutuhkan bantuan lagi dari para pendamping, maka tahap pendampingan akan dimulai lagi dari awal, misalnya pada korban kekerasan seksual yang mengalami trauma ke-dua maka akan dirujuk kembali ke psikolog begitu seterusnya.

Makna pendampingan bagi anak disini adalah sebagai sumber penguatan bagi anak, karena anak merasa tidak sendirian dalam menghadapi permasalahan. Ada para pendamping yang senantiasa dan membantu anak sehingga anak menjadi semangat dan tidak putus asa dalam menghadapi permasalahan dan dapat melanjutkan masa depannya. Dengan pendampingan ini anak akan merasa lebih nyaman mengungkapkan semua yang dia rasakan dan dia alami karena sudah tidak ada rasa canggung lagi antara anak dan pendamping. Sedangkan makna pendampingan bagi orang tua yaitu sebagai orang tua merasa sangat senang karena sangat terbantu oleh para pendamping dalam penyelesaian masalah anak mereka.

Dengan adanya pendampingan ini orang tua lebih kuat dalam menghadapi masalah yang menimpa anak mereka karena ada para pendamping yang selalu memberikan penguatan kepada seluruh keluarga dan senantiasa membantu serta memantau perkembangan kondisi anak. Di rumah pun orang tua ikut berperan dalam memberikan penguatan baik keagamaan maupun dalam pemulihan psikologis agar pendampingan berjalan maksimal dan kondisi anak juga dapat pulih dengan maksimal.

Hal ini sejalan dengan pendapat yang disampaikan Juni Thamrin banyak cara untuk melakukan pendampingan dan salah satunya yaitu kunjungan ke lapangan, tujuan kunjungan ke lapangan ini adalah membina hubungan kedekatan dengan anak-anak korban kekerasan. Kedekatan yang dihasilkan akan semakin menumbuhkan kepercayaan dalam diri anak bahwa kita (pendamping) sungguh menjadi sahabat, kakak dan sekaligus orang tua bagi mereka. Alasan turun langsung ke jalan/lapangan yaitu untuk lebih mengenal dan memahami kondisi realita anak korban kekerasan. Dengan turun langsung ke jalan/lapangan akan menumbuhkan kepercayaan diri dan kesadaran anak korban kekerasan untuk terbuka dan merasa nyaman karena pendamping memposisikan dirinya menjadi pribadi yang sejajar dan setara dengan anak korban kekerasan sebagai kakak, sahabat sekaligus orang tua. Dengan sikap keterbukaan dari anak, maka pendamping dapat mengidentifikasi akar permasalahan dari anak korban kekerasan sehingga dapat menemukan solusi/tindak lanjut terhadap permasalahan anak.

\section{Hambatan-hambatan Dinas Sosial Pengendalian Penduduk Keluarga Berencana Pemberdayaan Perempuan dan Perlindungan Anak (Dinsos P2KBP3A) dalam menurunkan tingkat kekerasan terhadap anak di Kabupaten Bungo}

Berdasarkan wawancara dengan infroman penelitian diketahui bahwa terdapat beberapa hambatan yang dialami Dinas Sosial Pengendalian Penduduk Keluarga Berencana Pemberdayaan Perempuan dan Perlindungan Anak (Dinsos P2KBP3A) dalam menurunkan tingkat kekerasan terhadap anak di Kabupaten Bungo:

Minimnya Pengetahuan masyarakat dan orang tua tentang Kekerasan terhadap anak

Minimnya Pengetahuan masyarakat dan orang tua tentang Kekerasan terhadap anak menjadi hambatan bagi Dinsos P2KBP3A Kabupaten Bungo dalam menurunkan tingkat kekerasan terhadap anak di Kabupaten Bungo, karena banyak tindak kekerasan yang dilakukan dalam keluarga yang dianggap bukan merupakan tindak kekerasan. Hal ini sebagaimana disampaikan oleh Bapak Systam Efendi selaku P2TP2 Kabupaten Bungo:

“....masyarakat kita masih minim sekali pengetahuannya tentang tindak kekerasan, sehingga mereka mengganggap apa yang mereka lakukan seolah-olah bukan tindak kekerasan, padahal tindakan kekerasan terhadap anak itu sangat luas sekali pengertiannya, tindak kekerasan rumah

${ }^{16}$ Wawancara dengan Systam Efendi selaku P2TP2 Kabupaten Bungo, tanggal 7 Agustus 2018 
tangga yang termasuk di dalam tindakan kekerasan rumah tangga adalah memberikan penderitaan baik secara fisik maupun mental di luar batas-batas tertentu terhadap orang lain yang berada di dalam satu rumah..." 17

\section{Beliau melanjutkan:}

“..banyak orangtua menganggap kekerasan pada anak adalah hal yang wajar. Mereka beranggapan kekerasan adalah bagian dari mendisiplinkan anak. Mereka lupa bahwa orangtua adalah orang yang paling bertanggung jawab dalam mengupayakan kesejahteraan, perlindungan, peningkatan kelangsungan hidup, dan mengoptimalkan tumbuh kembang anaknya...." 18

Keluarga adalah tempat pertama kali anak belajar mengenal aturan yang berlaku di lingkungan keluarga dan masyarakat. Sudah barang tentu dalam proses belajar ini, anak cenderung melakukan kesalahan. Bertolak dari kesalahan yang dilakukan, anak akan lebih mengetahui tindakan-tindakan yang bermanfaat dan tidak bermanfaat, patut atau tidak patut. Namun orang tua menyikapi proses belajar anak yang salah ini dengan kekerasan. Bagi orangtua, tindakan anak yang melanggar perlu dikontrol dan dihukum. Bagi orangtua tindakan yang dilakukan anak itu melanggar sehingga perlu dikontrol dan dihukum.

Luka yang diakibatkan bisa berupa luka fisik, perasaan, pikiran, yang merugikan kesehatan dan mental.kekerasan anak, kekerasan pada anak adalah segala bentuk tindakan yang melukai dan merugikan fisik, mental, dan seksual termasuk hinaan meliputi: Penelantaran dan perlakuan buruk, Eksploitasi termasuk eksploitasi seksual, serta trafficking/ jual-beli anak. Sedangkan child abuse adalah semua bentuk kekerasan terhadap anak yang dilakukan oleh mereka yang seharusnya bertanggung jawab atas anak tersebut atau mereka yang memiliki kuasa atas anak tersebut, yang seharusnya dapat di percaya, misalnya orang tua, keluarga dekat, dan guru.

Secara umum dapat disimpulkan bahwa kekerasan terhadap anak adalah segala bentuk perlakuan baik secara fisik maupun psikis yang berakibat penderitaan terhadap anak. Beberapa kriteria yang termasuk perilaku menyiksa dan kekerasan adalah: (1) Menghukum anak secara berlebihan; (2) Memukul; (3) Menyulut dengan ujung rokok, membakar, menampar, membanting; (4) Terus menerus mengkritik, mengancam, atau menunjukkan sikap penolakan terhadap anak; (5) Pelecehan seksual; (6) Menyerang anak secara agresif; (7) Mengabaikan anak; tidak memperhatikan kebutuhan makan, bermain, kasih sayang dan memberikan rasa aman yang memadai

Minimnya partisipasi masyarakat dalam melaporkan kejadian tindak kekerasan pada anak

Hambatan lainnya yang dialami Dinas Sosial Pengendalian Penduduk Keluarga Berencana Pemberdayaan Perempuan dan Perlindungan Anak (Dinsos P2KBP3A) dalam menurunkan tingkat kekerasan terhadap anak adalah minimnya partisipasi masyarakat dalam melaporkan kejadian tindak kekerasan pada anak. Hal ini sebagaimana disampaikan oleh Bapak Systam Efendi selaku P2TP2 Kabupaten Bungo, berikut penuturannya:

“.....masih banyak kejadian yang tidak dilaporkan masyarakat, karena berbagai pertimbangan, seperti adanya ketakukan dari masyarakat untuk melaporkan kejadian yang terjadi didepan mata mereka, dengan alasan tidak mau ikut campur dalam rumah tangga orang lain.." 19

\section{Upaya Dinas Sosial Pengendalian Penduduk Keluarga Berencana Pemberdayaan Perempuan dan Perlindungan Anak (Dinsos P2KBP3A) dalam mengatasi hambatan untuk menurunkan tingkat kekerasan terhadap anak di Kabupaten Bungo}

Berdasarkan wawancara dengan beberapa informan diketahui bahwa upaya Dinas Sosial Pengendalian Penduduk Keluarga Berencana Pemberdayaan Perempuan dan Perlindungan Anak (Dinsos P2KBP3A) dalam mengatasi hambatan untuk menurunkan tingkat kekerasan terhadap anak di Kabupaten Bungo, diantaranya adalah:

Meningkatkan sosialisasi ke masyarakat

\footnotetext{
${ }^{17}$ Wawancara dengan Systam Efendi selaku P2TP2 Kabupaten Bungo, tanggal 7 Agustus 2018

${ }^{18}$ Wawancara dengan Systam Efendi selaku P2TP2 Kabupaten Bungo, tanggal 7 Agustus 2018

${ }^{19}$ Wawancara dengan Systam Efendi selaku P2TP2 Kabupaten Bungo, tanggal 7 Agustus 2018
} 
Mengingat masih minimnya Pengetahuan masyarakat dan orang tua tentang kekerasan terhadap anak maka upaya yang dilakukan oleh Dinas Sosial Pengendalian Penduduk Keluarga Berencana Pemberdayaan Perempuan dan Perlindungan Anak Kabupaten Bungo dengan memberikan sosialisasi ke masyarakat. Sosialisasi ini mengajak seluruh masyarakat Kabupaten Bungo untuk berkontribusi langsung agar menghentikan kekerasan pada anak dan melindungi anak dari segala bentuk kekerasan. Hal ini sebagaimana disampaikan oleh Bapak Systam Efendi selaku P2TP2 Kabupaten Bungo, berikut penuturannya:

“...kita mencoba melakukan sosiaslisasi diberbagai forum kegiatan agar ada upaya bersama untuk menghentikan tidak kekerasan terhadap anak, banyak hal yang bisa dilakukan dengan cara berpartisipasi aktif maupun pasif dengan memberikan edukasi baik secara offline maupun online untuk menyebarkan informasi ke mayarakat luas..." 20

Untuk menyukseskan sosialisasi yang sudah dibentuk untuk menurunkan angka kekerasan pada anak, sangat diperlukan kontribusi dari semua pihak. Termasuk dari masyarakat sendiri. Orangtua harus paham betul mengenai pentingnya anak dan peran anak dalam keluarga serta memperbaiki pola asuh menjadi lebih mendidik dan melindungi anak. Perlu dilakukan edukasi dari rumah ke rumah mengenai dampak dari kekerasan pada anak agar keluarga juga lebih terpapar. Warga yang pernah melihat tindak kekerasan juga perlu secara aktif melaporkan.

Penyediaan Rumah Aman

Minimnya partisipasi masyarakat dalam melaporkan kejadian tindak kekerasan pada anak karena berbagai alasan, maka upaya yang dilakukan Dinas Sosial adalah berupaya untuk menyediakan rumah aman, hal ini bertujuan untuk menjaga keamana bagi si korban sehingga ketakutan dari masyarakat dalam melaporkan kejadian dapat teratasi, hal ini sebagaimaan diungkapkan Bapak Systam Efendi selaku P2TP2 Kabupaten Bungo, berikut penuturannya:

“....tahun 2018 ini kita sudah mengupayakan adanya rumah aman bagi korban tindak kekerasan, karena selama ini ada kekhawatiran dari masyarakat jika tidak ada rumah aman ditakutkan korban menjadi ancaman pelaku..." 21

Beliau melanjutkan :

“....dengan adanya Rumah Aman sendiri agar bisa melayani dengan lebih baik memberikan pengamanan dan perlindungan yang lebih baik dan memberikan fasilitas penunjang untuk Rumah Aman dan dapat menjaga privasi korban kekerasan.

Berdasarkan dokumen anggaran perubahan 2018 pada Dinas Sosial P2KB dan P3A Kabupaten Bungo diketahui bahwa terdapat Rp. 5.473 .400 untuk belanja peralatan kebersihan dan bahan pembersih rumah aman, Rp. 92.380.000 untuk belanja modal (perlengkapan rumah aman seperti lemari pakaian, mesin pompa air, kursi lipat, kasur busa, karpet dan lain-lain) serta Rp. 75.000.000 untuk renovasi rumah aman.

\section{SIMPULAN}

Model pendampingan yang dilakukan Dinas Sosial merupakan pendampingan dalam bentuk anggaran dan kebijakan, namun untuk pelaksanaan pendampingan secara langsung terhadap anak sebagai korban tindak kekerasan dilakukan oleh Pusat Pelayanan Terpadu Pemberdayaan Perempuan dan Anak (P2TP2A), beberapa pendampingan yang dilakukan P2TP2A terhadap anak korban kekerasan yaitu pendampingan medis, pendampingan psikologis, dan pendampingan yuridis.

Beberapa hambatan yang dialami Dinas Sosial Pengendalian Penduduk Keluarga Berencana Pemberdayaan Perempuan dan Perlindungan Anak (Dinsos P2KBP3A) dalam menurunkan tingkat kekerasan terhadap anak di Kabupaten Bungo, diantaranya adalah minimnya Pengetahuan masyarakat dan orang tua tentang Kekerasan terhadap anak dan minimnya partisipasi masyarakat dalam melaporkan kejadian tindak kekerasan pada anak.

\footnotetext{
${ }^{20}$ Wawancara dengan Systam Efendi selaku P2TP2 Kabupaten Bungo, tanggal 7 Agustus 2018

${ }^{21}$ Wawancara dengan Systam Efendi selaku P2TP2 Kabupaten Bungo, tanggal 7 Agustus 2018
} 
Jurnal Politik dan Pemerintah Daerah, 1 (2), 2019 - 73

Abu Nawar, Joko Setyoko

Upaya Dinas Sosial Pengendalian Penduduk Keluarga Berencana Pemberdayaan Perempuan dan Perlindungan Anak (Dinsos P2KBP3A) dalam mengatasi hambatan untuk menurunkan tingkat kekerasan terhadap anak di Kabupaten Bungo, diantaranya adalah meningkatkan sosialisasi ke masyarakat dan penyediaan rumah aman.

Diharapkan Dinas Sosial Pengendalian Penduduk Keluarga Berencana Pemberdayaan Perempuan dan Perlindungan Anak Kabupaten Bungo meningkatkan dukungannya terhadap P2TP2A dengan melakukan penguatan kelembagaan, agar keberadaan P2TP2A mampu mengurangi tindakan kekerasan terhadap di Kabupaten Bungo

\section{DAFTAR PUSTAKA}

Arikunto, S. (2006). Prosedur penelitian suatu pendekatan praktik. Jakarta: Rineka Cipta.

Bupati Bungo. (2018).Peraturan Daerah Kabupaten Bungo nomor 7 tahun 2018 tentang Perlindungan Anak

Iriani, D., \& Iziyana, W. V. (2019). Pemilihan Gubernur, Bupati dan Walikota dan Persepsi Komisi Pemilihan Umum Kota Madiun. JUSTITIA JURNAL HUKUM, 3(1).

Moleong, L. J. (2007). Metodologi penelitian kualitatif, Bandung: PT Remaja Rosdakarya.

Noerwiyati, W. (2017). Analisis pengaruh pelaksanaan penilaian portofolio terhadap prestasi belajar kewarganegaraan pembahasan hakikat bangsa dan negara siswa kelas IX-A SMP Negeri 2 Bangkalan. Jurnal Civic Education: Media Kajian Pancasila dan Kewarganegaraan, 1(2), 1425.

Presiden Republik Indonesia (2002). Undang-Undang Republik Indonesia Nomor 23 Tahun 2002 tentang perlindungan anak

Sari, N. (2015). Penegakan hukum undang-undang KDRT. Yogyakarta: GRE Publishing

Setyawan, D. (2014). KPAI: Kasus Kekerasan terhadap Anak Meningkat. Retrived from https://www.kpai.go.id/berita/kpai-kasus-kekerasan-terhadap-anak-meningkat

Thohari, A. A. (2005). Konseptualisasi Negara Hukum dan Demokrasi; Upaya Menuju Negara yang Dicita-citakan. Lex Jurnalica, 3(1), 17949. 